\title{
Factors influencing biogenic amines accumulation in dairy products
}

\author{
Daniel M. Linares, Beatriz del Río, Victor Ladero, Noelia Martínez, María Fernández, María Cruz Martín and \\ Miguel A. Álvarez*
}

Instituto de Productos Lácteos de Asturias, (IPLA - CSIC), Villaviciosa, Spain

Edited by:

Giovanna Suzzi, University of Teramo,

Italy

Reviewed by:

Giuseppe Spano, University of Foggia, Italy

Maria Martuscelli, University of

Teramo, Italy

*Correspondence:

Miguel A. Álvarez, Instituto de

Productos Lácteos de Asturias,

Carretera de Infiesto s/n. 33300

Villaviciosa, Spain.

e-mail: maag@ipla.csic.es
Fermented foods are among the food products more often complained of having caused episodes of biogenic amines (BA) poisoning. Concerning milk-based fermented foods, cheese is the main product likely to contain potentially harmful levels of BA, specially tyramine, histamine, and putrescine. Prompted by the increasing awareness of the risks related to dietary uptake of high biogenic amine loads, in this review we report all those elaboration and processing technological aspects affecting BA biosynthesis and accumulation in dairy foods. Improved knowledge of the factors involved in the synthesis and accumulation of BA should lead to a reduction in their incidence in milk products. Synthesis of $\mathrm{BA}$ is possible only when three conditions converge: (i) availability of the substrate amino acids; (ii) presence of microorganisms with the appropriate catabolic pathway activated; and (iii) environmental conditions favorable to the decarboxylation activity. These conditions depend on several factors such as milk treatment (pasteurization), use of starter cultures, $\mathrm{NaCl}$ concentration, time, and temperature of ripening and preservation, $\mathrm{pH}$, temperature, or post-ripening technological processes, which will be discussed in this chapter.

Keywords: biogenic amines, cheese, producing microorganisms, pasteurization, starters, ripening, chemicophysical factors

\section{INTRODUCTION}

Fermented foods, and especially cheese, are within the food products more often related with biogenic amines (BA) poisoning (Sumner et al., 1985; EFSA Panel on Biological Hazards (BIOHAZ), 2011). Under normal conditions, exogenous BA ingested with food are rapidly detoxified by the action of amine oxidases, but whenever the detoxification process is disturbed, or the BA concentration in food is very high, BA become toxic metabolites responsible of serious human health problems (Repka-Ramírez and Baraniuk, 2002; Soufleros et al., 2007; Ladero et al., 2010a; Spano et al., 2010). In the 60s of last century, a close relation between migraine crisis and ingestion of tyramine-rich food (especially cheese) was observed (Blackwell, 1963; Hanington, 1967; Coutts et al., 1986). In fact, these effects of tyramine consumption were coined as cheese-reaction. Despite the toxicity of BA, their limit concentrations in fermented foodstuffs have not yet been adequately standardized by regulatory agencies.

The most important BA in dairy foods are histamine, tyramine (produced by enzymatic decarboxylation of histidine and tyrosine, respectively), putrescine (synthesized via ornithine decarboxylation or agmatine deamination), and to a minor extent, cadaverine (originated by lysine decarboxylation; Linares et al., 2011). These amino acid decarboxylating activities are mainly attributable to the microbial groups that participate in the fermentation process.

Many bacteria of different genera and species have the capacity to produce BA. Gram negative bacteria (mainly Enterobacteriaceae) that can be present in milk are able to produce histamine, putrescine, and cadaverine (ten Brink et al., 1990; Marino et al., 2000; Pircher et al., 2007). However, the main BA producers in cheese are mostly lactic acid bacteria (LAB) included in the genera Enterococcus, Lactobacillus, Leuconostoc, Lactococcus, and Streptococcus (Fernández et al., 2004; Martín et al., 2005; Bonetta et al., 2008; Calles-Enríquez et al., 2010; Ladero et al., 2011a). These Gram positive bacteria can be present: (i) in the milk, (ii) introduced by contamination throughout the entire process of cheese production, (iii) and may even be part of starter or adjunct cultures. Several authors have reported the presence of tyrosine and histamine decarboxylase activity in strains from various starter cultures (Burdychova and Komprda, 2007; Calles-Enríquez et al., 2010; La Gioia et al., 2011).

Consequently, formation of BA can occur during food processing and storage as a result of bacteria that have amino acid decarboxylase activities. The manufacture of dairy foods is not a sterile process, and BA producers are likely to enter the food chain as non-starter $\mathrm{LAB}$ that are indigenous to the raw material. Besides the presence of microorganisms with the appropriate metabolic pathway, BA formation is only possible if there is availability of the free substrate amino acids and the environment conditions are favorable to the decarboxylation activity (Russo et al., 2010). There are different factors related with such conditions: the milk treatments, the use of starter cultures and enzymes, the duration and the temperature of ripening, the level of proteolysis, the $\mathrm{pH}$, the $\mathrm{NaCl}$ concentration, the presence of oxygen, the activity of water and the relative humidity, the bacterial density and synergistic effect between microorganisms are the most important (Gardini et al., 2001). In spite of great technological advantages, much of the dairy fermentations are still based on traditional, experiencedbased techniques that are strongly rooted in specific geographic 
regions. As a result, these factors can not always be modified in order to reduce the accumulation of BA without modifying the organoleptic and sensory properties of the final product.

Cheese represents an ideal matrix for production of BA because it is not sterile and the casein proteolysis ensures the availability of free substrate amino acids. Therefore, BA can reach concentrations in cheese up to $2000 \mathrm{mg} \mathrm{kg}^{-1}$ (Roig-Sagués et al., 2002; Fernández et al., 2007a). Ingestion of cheese containing such a high concentration of BA is a direct threat to the consumer, especially in places like Europe where cheese is one of the major foods in the diet. The consumption of cheese in Europe in 2009 was $16.6 \mathrm{~kg}$ per capita [International Dairy Federation (IDF) Bulletin 446/2010, Statistics Canada]. However, BA concentration differs widely between different cheeses because depends - as indicated previously - on several factors.

Beside cheese, kefir is another fermented dairy product where BA may be present. Recently, Özdestan and Üren (2010) reported total BA contents in kefir samples between 2.4 and $35.2 \mathrm{mgl}^{-1}$, being tyramine the prevailing BA. Similarly, Chaves-López et al. (2011) reported a total BA content of $15.31 \mathrm{mgl}^{-1}$ in kumis, a traditional Colombian fermented cow milk. Nevertheless, these levels are far below the recommended limits. Other milk-based fermented products including buttermilk or yogurt are not likely to contain significant levels of BA (Novella-Rodríguez et al., 2000; Souci et al., 2000). In the milk itself, the polyamines spermidine and spermine are the prevalent accumulated BA (Spano et al., 2010), however it remains unclear whether they are synthesized by microorganisms or they have an endogen origin.

Prompted by the increasing awareness of the risks related to dietary uptake of BA and the general agreement that they should not be allowed to accumulate in food, in this chapter we report about technological aspects affecting BA levels during cheese elaboration and processing. It should be noted that the control of these technological factors can be useful for the reduction of the BA accumulation on the final products.

\section{OCCURRENCE OF BIOGENIC AMINES IN DAIRY PRODUCTS}

Milk-based fermented foods, especially cheese, provide an adequate environment for BA production and accumulation (RoigSagués et al., 2002; Fernández et al., 2006a). However, big differences have been noted from different types of cheeses, which has been related to bacterial counts in the milk, thermal milk treatment intensity or duration and the length and conditions of the ripening process. The use of starter cultures could also influence the production of BA either directly or indirectly through the interaction with the wild cheese microbiota (Ordóñez et al., 1997). Beside this, a different distribution of BA through the cheese has been observed (Novella-Rodríguez et al., 2003). All these variables contribute to the enormous differences observed between different types of cheeses or even in the same type of cheese depending on the part analyzed or the ripening period. In order to offer an overview of BA content in dairy products, the data available in the literature have been summarized in Table 1.

\section{BA-PRODUCING MICROORGANISMS IN DAIRY PRODUCTS}

One of the indispensable conditions for the presence and further accumulation of BA in fermented dairy products is the presence of microorganisms with the capacity to synthesize these toxic compounds. Among those microorganisms that have been identified as usual microbiota of cheeses, some of them have been identified as BA producers including yeast, Gram positive and Gram negative bacteria (Table 2), although not all of them have an impact in the presence of high concentrations of BA in the final product.

Several yeasts species have been described as potential producers of aliphatic amines (putrescine and cadaverine; Suzzi et al., 2003). However, only a few strains of Debaryomyces hansenii and Yarrowia lipolytica isolated from cheese seem to be able to produce histamine and tyramine respectively (Gardini et al., 2006). The presence of Y. lipolytica, Pichia jadinii, or Geotrichum candidum has been related in some cases (Wyder et al., 1999; Roig-Sagués et al., 2002) with an increase in the concentration of histamine and putrescine.

Most of the Gram negative bacteria described as usual contaminants of milk are able to produce histamine, putrescine, or cadaverine, i.e., Escherichia coli, Hafnia alvei, Klebsiella pneumoniae, Morganella morganii, Pseudomonas, or Serratia spp (Marino et al., 2000; Roig-Sagués et al., 2002; Coton et al., 2011). However, the presence of elevated concentrations of Gram negative bacteria - especially Enterobacteriaceae - has been only correlated in some cases with an increase in the concentration of putrescine or cadaverine (ten Brink et al., 1990; Pircher et al., 2007; Delbès-Paus et al., 2012). In those cases, BA are result of bad manufacturing practices, poor quality or insufficient hygienic conditions.

Nevertheless, the main BA producers in cheese are Gram positive bacteria, being $\mathrm{LAB}$ the main histamine and tyramine producers (Linares et al., 2011). Moreover, recent discoveries pointed out the importance of this bacterial group as putrescine producers (Ladero et al., 2011a, 2012a). The genera Enterococcus, Lactobacillus, Lactococcus, Leuconostoc, and Streptococcus include some strains belonging to different species that have been described as BA producers (Table 2). Other LAB have been described as BA producers in some reports such as tyramine producing lactococci or lactobacilli (Fernández et al., 2004; Bunková et al., 2009; Nieto-Arribas et al., 2009). However, the identification of the species is not based on the sequencing of the 16S rRNA gene, or other gene with taxonomical relevance, which could lead to misclassification (Delgado and Mayo, 2004; Fernández et al., 2007b). All these BA-producing LAB belong to species that are normal microbiota of milk and cheese (Varnam and Sutherland, 1994) and can be potentially present during the elaboration of any fermented dairy product (Novella-Rodríguez et al., 2002; Ladero et al., 2009; Linares et al., 2011).

\section{FACTORS INFLUENCING BIOGENIC AMINE PRODUCTION IN DAIRY PRODUCTS}

The biosynthesis and accumulation of BA in dairy foods requires the presence of bacteria with decarboxylase activity, the appropriate environmental conditions for their growth and the activity of the decarboxylases, and the presence of the substrate amino acids. The influence of all these parameters in BA production is addressed in this section. 
Table 1 | Biogenic amine content in dairy products $(\mathrm{mg} / \mathrm{kg})$.

\begin{tabular}{|c|c|c|c|c|c|c|c|c|c|c|}
\hline Source & & Type & Cad & His & Phe & Put & Tyr & Spn & Spd & Reference \\
\hline \multirow[t]{4}{*}{ Milk } & Raw & Cow & nd & nd & nd & nd & nd & 0.18 & nd & Novella-Rodríguez et al. (2000) \\
\hline & & & - & 0.3 & - & - & - & - & - & Bodmer et al. (1999) \\
\hline & & Ewe & - & - & - & - & - & nd & nd & Pinho et al. (2004) \\
\hline & Pasteurized & Cow & - & 0.7 & - & - & - & - & - & Bodmer et al. (1999) \\
\hline \multirow[t]{2}{*}{ Yogurt } & & & - & 13 & - & - & - & - & - & Bodmer et al. (1999) \\
\hline & & & 0.27 & nd & nd & nd & nd & 0.43 & 0.34 & Novella-Rodríguez et al. (2000) \\
\hline Cheese & & Sheep & 123.07 & 50 & - & 107.69 & 125 & 115.38 & 369.23 & Mercogliano et al. (2010) \\
\hline \multirow[t]{9}{*}{ (raw milk) } & & Sheep & 26.8 & 0 & 28.6 & 394.1 & 499.6 & 96.4 & & Schirone et al. (2011) \\
\hline & & Goat & 349.72 & 15.6 & 9.39 & 217.84 & 216.28 & nd & nd & Pinho et al. (2004) \\
\hline & & Goat & 88.7 & 88.4 & 11.7 & 191.8 & 830.5 & - & - & Novella-Rodríguez et al. (2002) \\
\hline & & Goat & 94 & 117 & 160 & 941 & 258 & 70.5 & 23.5 & Galgano et al. (2001) \\
\hline & & Cow & nd & nd & nd & nd & nd & nd & nd & Fernández et al. (2007b) \\
\hline & & Cow & nd & nd & nd & nd & nd & nd & nd & Fernández et al. (2007b) \\
\hline & Parmigiano & Cow & 3.2 & 10.9 & - & 1.8 & 6.4 & 4.4 & - & Mayer et al. (2010) \\
\hline & Parmigiano & Cow & 15.56 & 28.55 & 9.51 & 75.87 & 29.89 & 7.71 & 4.46 & Innocente and D'Agostin (2002) \\
\hline & Extra hard grana & Cow & & 249 & - & & 18 & - & - & Mayer et al. (2010) \\
\hline Cheese & Feta & Goat & 82.8 & 84.6 & 4.94 & 193 & 246 & nd & nd & Valsamaki et al. (2000) \\
\hline (pasteurized & Emmental Hard & Cow & 98.3 & 23.5 & - & 38 & 52.2 & - & 16.8 & Mayer et al. (2010) \\
\hline \multirow[t]{12}{*}{ milk) } & Cheddar & Cow & nd & 25.4 & - & 4.8 & - & 8.5 & 18.2 & Mayer et al. (2010) \\
\hline & Semi hard & Cow & nd & - & - & - & 24.3 & 5.0 & 17.3 & Mayer et al. (2010) \\
\hline & Gouda & Cow & nd & - & - & - & 2.43 & 0.5 & 1.73 & Mayer et al. (2010) \\
\hline & Edam & Cow & nd & 3.2 & - & - & - & - & - & Mayer et al. (2010) \\
\hline & Gorgonzola & Cow & nd & 23.7 & - & - & - & - & - & Mayer et al. (2010) \\
\hline & Gorgonzola & Cow & 33.7 & 255.3 & - & 3.2 & 13.2 & 10.8 & 17.2 & Mayer et al. (2010) \\
\hline & Smear & Cow & 748.2 & 168.3 & - & 31.3 & 247.6 & 18.5 & 16.6 & Mayer et al. (2010) \\
\hline & Semiripenned & Cow & 33.49 & 24.38 & 25.75 & 22.6 & 32.92 & 24.35 & 23.4 & Latorre-Moratalla et al. (2009) \\
\hline & & Cow & nd & 65.42 & - & 175.39 & 80.9 & - & - & Fernández et al. (2007b) \\
\hline & & Goat & nd & 27.68 & - & 18.12 & 30.48 & - & - & Fernández et al. (2007b) \\
\hline & & Sheep & nd & nd & - & nd & 301.6 & - & - & Fernández et al. (2007b) \\
\hline & Pecorino Abruzzese & Sheep & 80 & 90 & 300 & 200 & 280 & nd & 20 & Martuscelli et al. (2005) \\
\hline Cheese & Roquefort & & 8.9 & 9.9 & 7.7 & 18.3 & & 4.6 & 18.1 & Mayer et al. (2010) \\
\hline \multirow[t]{4}{*}{ (blue) } & & & nd & 50 & nd & 25 & 2000 & nd & 18 & Rabie et al. (2011) \\
\hline & & & 2101.4 & 376.6 & 39.7 & 257.2 & 1585.4 & - & - & Novella-Rodríguez et al. (2003) \\
\hline & & Mixture & 756.78 & 1041.81 & 875.8 & 1051.98 & - & - & - & Fernández et al. (2007b) \\
\hline & & & 489.4 & 127.2 & - & 237.56 & 526.63 & - & - & Fernández et al. (2007b) \\
\hline \multirow[t]{2}{*}{ Kefir } & & & 1.8 & 4.0 & nd & 12.1 & 12.8 & nd & 4.5 & Özdestan and Üren (2010) \\
\hline & & & 2.2 & 1.6 & nd & 1.4 & 9.8 & nd & 1.5 & Özdestan and Üren (2010) \\
\hline
\end{tabular}

Cad, cadaverine; His, histamine; Phe, 2-phenilethylamine; Put, putrescine; Tyr, tyramine; Spn, spermine; Spd, spermidine; nd, undetected; -, not determined.

\section{ROLE OF BA-PRODUCING MICROORGANISMS}

The presence of BA-producing microorganisms is an indispensable condition for the biosynthesis of these toxic compounds. However, their accumulation in high concentrations depends not only on the presence of these BA-producing microorganisms but also if they reach a minimum number, and the coincidence of different factors during the elaboration and storage of the dairy products (Joosten and Northolt, 1987; Ladero et al., 2008). In general, it was difficult to find a correlation between the presence of high concentrations of BA in cheeses with and increment of a specific group or population of LAB. This was due to two main causes: (i) the fact that the capability to produce BA is mostly related to strain rather than to specie (Novella-Rodríguez et al., 2002) and (ii) the use of non-specific methods for the identification of these bacteria.

Certainly, the presence of the capability to produce BA in LAB has been described as a characteristic acquired through horizontal gene transfer associated to plasmids, mobile elements, or acidic resistance islands (Lucas et al., 2005, 2007; Marcobal et al., 2006b). However, in certain cases this trait can be considered as speciescharacteristic, such as the production of tyramine in Enterococcus (Ladero et al., 2012a) or that of putrescine in Lactococcus (Ladero et al., 2011a). In this latter case, it seems that the adaptation to the 
Table 2 | BA-producing microorganisms from dairy products.

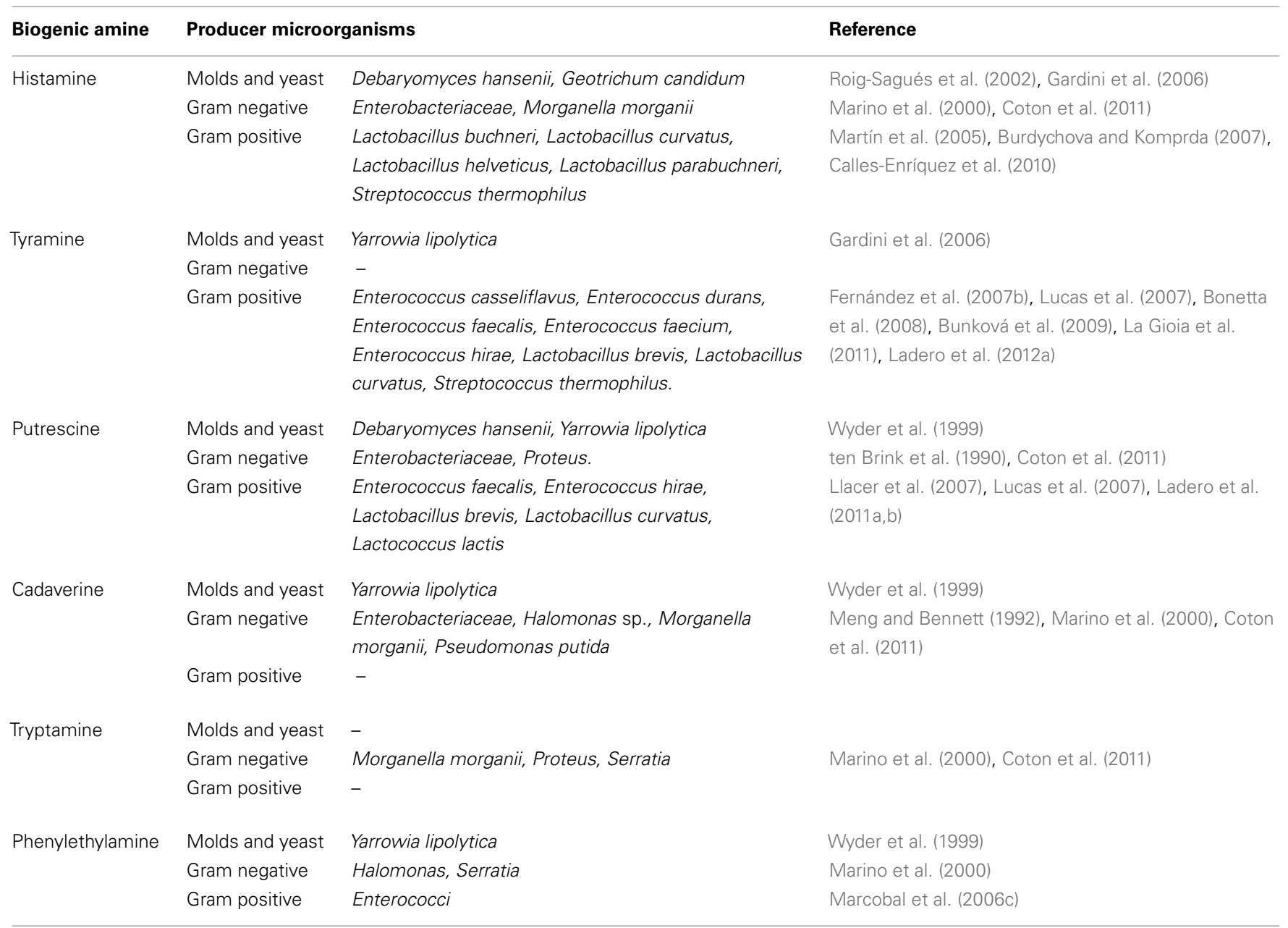

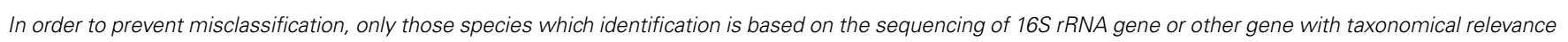
have been included in the table.

milk environment and/or the empirical selective pressure exerted because of the use of the strains as fermentation starters resulted in the inactivation or even the loss of the capability to produce putrescine, a compound that confers undesirable flavor.

The development of molecular methods toward the specific detection and quantification of BA producers in dairy products (Fernández et al., 2006a; Ladero et al., 2010b,c, 2012b) allowed to establish a direct relationship between the number of BA-producing microorganisms and the final BA concentration (Ladero et al., 2008, 2010b, 2012b). A minimum number of these BA producers has been proposed to reach high concentrations of BA in the final product (Joosten and Northolt, 1987; Ladero et al., 2008, 2010b).

\section{STARTER CULTURES}

In most industrial dairy fermentations, starter cultures are used to ensure the standard quality of the final products. Some LAB generally used as starter cultures, may have specific amino acid decarboxylase activities and thus, the potential to synthesize BA that could be accumulated in the dairy products. Belonging to this group are lactococci, lactobacilli and streptococci, as mentioned in the previous section.
The risk of incorporating BA-producing strains can be minimized by using well-characterized starter cultures, excluding those strains with the undesirable potential to produce BA. Several strains of Streptococcus thermophilus (Calles-Enríquez et al., 2010; La Gioia et al., 2011), Lactobacillus brevis and Lactobacillus curvatus (Ladero et al., 2011b), and Lactococcus lactis (Ladero et al., 2011a) obtained from dairy sources have been identified as histamine, tyramine, or putrescine producers. This becomes particularly relevant if we consider that strains belonging to those species are frequently used as starter cultures for cheese production. Burdychova and Komprda (2007) have isolated a histamine-producing Lactobacillus helveticus strain from a starter used for cheese production. Similarly, other Lactobacillus spp. isolated from ripened cheese, have been shown to produce BA such as tyramine (Straub et al., 1994; Arena et al., 2007; Ladero et al., 2011b) and also putrescine (Ladero et al., 2011b).

These facts led the recommendation to include the nonproduction of BA as a condition of strains intended to be used as starter cultures (Crow et al., 2001; Linares et al., 2011; EFSA Panel on Biological Hazards (BIOHAZ), 2011) or even raise the question about the addition of absence of $\mathrm{BA}$ production and $\mathrm{BA}$ 
production associated genes as qualification criteria in the "Qualified Presumption of Safety" (QPS) assessment scheme introduced by the European Food Safety Agency (EFSA). For this assessment, molecular methods for the identification and quantification of BA producers are currently available (Fernández et al., 2006b; Torriani et al., 2008; Ladero et al., 2010b, 2012b).

Another approach to reduce the accumulation of BA in dairy products, could be the use of adjunct cultures that include bacteria capable to degrade BA (Leuschner and Hammes, 1998; Naila et al., 2010) as is proposed for fish sauce, sausage, or wine fermentation (Martuscelli et al., 2000; Fadda et al., 2001; Gardini et al., 2002; García-Ruiz et al., 2011; Zaman et al., 2011). In the case of cheeses it was described the use of Brevibacterium linens to catabolize histamine and tyramine during the elaboration of Munster cheese (Leuschner and Hammes, 1998; Leuschner et al., 1998).

\section{PASTEURIZATION}

Milk is a rich organic fluid that provides the necessary nutrients for the growth of different microorganisms. Indeed, microbial loads of up to $10^{7} \mathrm{cfu} \mathrm{ml}^{-1}$ may be reached if storage conditions are not adequate (Varnam and Sutherland, 1994). The main microbiological groups present in raw milk are mesophilic LAB (enterococci, lactococci, lactobacilli, or leuconostoc), enterobacteriaceae, and psychotropic microorganisms such as Pseudomonas or Acinetobacter (Varnam and Sutherland, 1994; Muir and Banks, 2003; Martuscelli et al., 2005; Serio et al., 2007). Members of all these groups have been described as BA producers (Linares et al., 2011).

Pasteurization is a heat treatment that reduces the microbial load of raw milk. It has long been used by dairy industry to extend the shelf-life of the dairy products by reducing the presence of spoilage bacteria, pathogens, and those microorganisms with the capacity to produce toxic compounds that would render products unsafe for consumption (Lewis, 2003). The aim of the pasteurization is not the absolute elimination of the bacteria present on the milk, but the reduction of the bacterial load to levels safe for health and to ensure that the fermentative process is not on risk. The pasteurization reduces the bacterial load present in milk, including the BA producers. Thereby, cheeses elaborated with pasteurized milk use to have lower BA concentrations than those made with raw milk (Novella-Rodríguez et al., 2002; Fernández et al., 2007a; Naila et al., 2010). However, it is possible to detect BA in cheeses elaborated with pasteurized milk and sometimes at elevated concentrations (Fernández et al., 2007a; Pircher et al., 2007). The contamination with BA-producing microorganisms during the manufacture of cheese, due to deficient hygienic conditions, has been proposed as explanation (Pircher et al., 2007; Ladero et al., 2009). Moreover, some BA-producing Lactobacillus and Enterococcus are resistant to pasteurization and could develop as secondary microbiota after the thermal treatment, resulting in the apparition of BA in the final product (Ladero et al., 2011b). Both facts explain the existence of cheeses made with pasteurized milk and relatively high levels of BA. Consequently, pasteurization itself is not the ultimate solution to the problem of BA. Some authors have suggested that hurdle technology combining pasteurization with other treatments, such as high pressure, might reduce the presence of BA in cheeses, although no results were obtained yet (Novella-Rodríguez et al., 2002; Ladero et al., 2011b). Finally, it is important highlight that even using milk of good microbiological quality, if it is inoculated with BA-producing starters, the problem would persist. Therefore, a good starter selection - taking into account the ability to produce BA - is essential.

\section{RIPENING PROCESS AND PROTEOLYSIS}

Cheese ripening involves a complex variety of biochemical processes that include degradation of the lactose, lipolysis, and the most complex process, the catabolism of the proteins or proteolysis. The ripening process is carried out by starter LAB and the secondary microbiota, which comprises non-starter LAB, propionic acid bacteria, molds, and yeasts (Beresford and Williams, 2004). Starter bacteria contribute to the protein break down (Lane and Fox, 1996; Lynch et al., 1997) while the non-starter LAB are responsible of the peptidolysis and the release of free amino acids (Muehlenkamp-Ulate and Warthesen, 1999). Some blue cheeses elaborated with raw milk show high levels of proteolytic activity - due to the action of the fungi - that correlates with a high accumulation of BA (Fernández et al., 2007a).

Ripening and proteolysis are very important factors affecting the accumulation of BA in cheeses (Fernández-García et al., 2000). The proteolysis rate increases with the ripening time, leading the accumulation of free amino acids that serve as substrate of decarboxylic activities, which ultimately derives in BA accumulation (Fernández et al., 2007a). In general, the longer the aging process, the higher the content of BA (Fernández et al., 2007a). There are several studies showing that long-ripened cheeses have high proteolysis rate, which contributes to the high level of BA found in these cheeses in comparison with short-ripened ones (Arlorio et al., 2003; Bunková et al., 2010; Ladero et al., 2010b). In the particular case of histamine, it is also common to find the highest concentrations in long-ripened cheeses, which suggest that proteolysis occurring during the ripening period increases the production and accumulation of histamine in cheeses (Fernández et al., 2006b; Ladero et al., 2008). The same trend was observed for tyramine accumulation (Fernández et al., 2007a; Ladero et al., 2010b).

The addition of proteinases to cheese milk or curd has shown to accelerate the cheese ripening process but also the availability of small peptides and amino acids (Núñez et al., 1991; Mohedano et al., 1998), which has a direct effect on the BA production (Fernández-García et al., 1999).

\section{CHEMICO-PHYSICAL FACTORS}

Many chemico-physical factors such as the $\mathrm{pH}$, salt concentration, and temperature can affect the BA-producing microorganism growth and the decarboxylic activities during the production of fermented dairy products. Some studies have investigated the effect of these factors on BA production, but little is known about the consequences of their interaction.

\section{pH}

Dairy fermentations are intrinsically associated to a low $\mathrm{pH}$ environment caused by the fermentation of lactose to lactic acid. Although the physiological role of BA biosynthesis may differ depending of the BA and the producing microorganism, it has been proposed as a system for neutralization of low extracellular $\mathrm{pH}$ that increases survival under acidic stress condition (Meng 
and Bennett, 1992; Rhee et al., 2002). In LAB, the theory most widely extended is that those strains with the specific amino acid decarboxylases, produce BA to counteract the acidic stress of some environments, as that of dairy fermentations (Bearson et al., 1997; Wolken et al., 2006). This theory is supported by the relation between the $\mathrm{pH}$ decrease and $\mathrm{BA}$ production observed in LAB (Marcobal et al., 2006a; Fernández et al., 2007b). Certainly, it is well known that low $\mathrm{pH}$ is a crucial factor for the activity of some amino acid decarboxylases (Chander et al., 1988; Teodorovic et al., 1994). There are in the literature different works describing an acid $\mathrm{pH}$ to be optimum for tyrosine decarboxylase (Moreno-Arribas and Lonvaud-Funel, 1999, 2001) and other bacterial amino acid decarboxylases (Gale, 1946; Schelp et al., 2001). Moreover, the genes encoding for the decarboxylases can be induced at low pH. Linares et al. (2009) revealed that the increased production of tyramine by Enterococcus durans under low $\mathrm{pH}$ conditions is prompted by a significant induction of the decarboxylase $(t d c A)$ and transporter ( $t y r P)$ genes expression, whereas they are not expressed at neutral $\mathrm{pH}$. Similarly, the $t d c$ and $\operatorname{aguA1}$ genes (involved in tyramine and putrescine production, respectively) of L. brevis are transcriptionally induced by low $\mathrm{pH}$ (Arena et al., 2010).

Overall, although some authors indicate that rapid acidification could reduce the levels of BA production related to a decrease in the growth of the decarboxylating microorganisms (Gardini et al., 2001), low $\mathrm{pH}$ is a key parameter which represents a potential risk of BA accumulation in the final product. However, it is difficult to act on this parameter, since it is inherent to the fermentation process.

\section{Temperature}

Temperature is a key parameter in the elaboration of cheeses and affects the accumulation of BA particularly during maturation and storage steps. In general, the production and accumulation of BA increases with the temperature during production and storage of cheese. The storage of the product includes the period between the last step of production - the ripening - until consumption. A number of studies show that low ripening and storage temperatures (e.g., $5^{\circ} \mathrm{C}$ ) decrease the accumulation of BA such as histamine, tyramine, putrescine, and cadaverine, while their content increases with higher temperatures (Stratton et al., 1991; Gardini et al., 2001; Pinho et al., 2001; Gennaro et al., 2003; Santos et al., 2003; Martuscelli et al., 2005; Bunková et al., 2010). A multifactorial study of factors influencing tyramine production by LAB revealed that high temperature play a role on tyramine production by L. brevis and Enterococcus faecium (Marcobal et al., 2006a). In addition, a histamine-producing $S$. thermophilus strain produces lower amounts of histamine when it is stored at low temperatures $\left(4^{\circ} \mathrm{C}\right)$ after its growth in milk. This reduction was attributed to a reduction in the activity of the histidine decarboxylase itself rather than a reduction in gene expression or the presence of a lower cell number (Calles-Enríquez et al., 2010).

It has been described that even if the cheese is kept in refrigeration, the BA accumulation could rise above the safe limits for consumption (Bunková et al., 2010). A step further, frozen temperature (e.g., $-18^{\circ} \mathrm{C}$ ) impairs the increase on the BA accumulation, most likely because the microbial activity is stopped (Andiç et al., 2010). However, more affordable solutions have to be found.

\section{Sodium chloride}

Another factor that might have an effect on BA accumulation is the concentration of salt in the fermented product. Traditionally salt has been employed to control the growth of pathogens during the fermentation and ripening process of dairy products with the last aim of preventing the spoilage and food-poisoning. Another consequence of the reduction on the growing rate of bacteria - including BA producers - would be the decrease of the BA concentration in the final product.

Most of the cheeses made with raw milk reach high numbers of Enterococcus spp., which is one of the main important BA producers in artisanal and traditional cheeses. The addition of high concentration of sodium chloride $(5 \%)$ to milk inoculated with Enterococcus faecalis, reduced to the minimum the amount of 2phenylethylamine and tyramine production (Gardini et al., 2001). The decrease on the BA production could be explained by the inhibitory effect of high salt content on the growth rate of BAproducing bacteria (Gardini et al., 2001) and/or on the amino acid decarboxylation activities (Chander et al., 1989). A similar effect of sodium chloride concentration has been observed in cheeses made of milk inoculated with Lactobacillus bulgaricus (Chander et al., 1989) or Lactobacillus buchneri (Sumner et al., 1990).

\section{POST-RIPENING TECHNOLOGICAL PROCESSES}

In the last decades, the market has reacted to customer requirements and it has evolved to sell ready-to-eat products (cut, sliced, grated. . .) instead of traditional formats such as the entire cheese. This ulterior processing implies more manipulation and the consequent increase of risk for microbial contamination (Reij and Den Aantrekker, 2004). The post-ripening process appears to have a direct impact in the presence of BA and BA producers. This could be due to the development of BA-producing bacteria present on the raw milk or to the contamination during the technological process (Custódio et al., 2007; Ladero et al., 2009).

Ladero et al. (2009), reported the effect of post-ripening process in the histamine-producing microbiota and the histamine content on a variety of cheeses. In some cases, histamine-producing bacteria were not found in the entire piece, but an increase on the number of histamine producers and histamine content was detected after grating. This result suggests an external contamination due to the post-ripening process. Thus, cheese grating seems to facilitate microbiological contamination due to the manipulation and the increase in the surface/volume ratio of the cheese fragments, which facilitates the presence of BA-producing bacteria and the subsequent accumulation of BA.

\section{CONCLUSION}

Safety is a basic requirement that must be always satisfied in food production. BA levels are unevenly distributed within cheese, where they can reach concentrations that represent a health risk, at least for those consumers with diminished detoxification system. Currently, there is no legislation defining the limits of BA tolerance in fermented foodstuff. However, cheese is the food that reach the highest BA concentrations, and therefore, a more severe control should be exercised. 
Greater knowledge of the factors involved in the synthesis and accumulation of BA should lead to a reduction in their incidence in dairy foods. The production of BA in cheese is a complex phenomenon that depends on several variables, such as the presence of BA-producing microorganisms, their proteolytic and decarboxylase activities, ripening time, ripening and storage temperature, etc. In this sense, acidic $\mathrm{pH}$ is described to enhance BA accumulation in vitro. However, similarly to other chemico-physical conditions (such as amino acid availability, temperature, or salt concentration), it becomes difficult to modify these parameters, since they are inherent to the fermentation process. This clearly indicates that key actions to prevent BA accumulation must be addressed toward a reduction of the numbers of BA-producer microorganisms during cheesemaking. So far, control of BAproducing microorganisms by adequate thermal treatment of milk is one of the most important factors for reducing BA accumulation in dairy products. Moreover, encouraging a more responsible production by improving hygienic conditions, selection of starters

\section{REFERENCES}

Andiç, S., Gençcelep, H., Tunçtürk, Y., and Köse, S. (2010). The effect of storage temperatures and packaging methods on properties of Motal cheese. J. Dairy Sci. 93, 849-859.

Arena, M. E., Fiocco, D., Manca de Nadra, M. C., Pardo, I., and Spano, G. (2007). Characterization of a Lactobacillus plantarum strain able to produce tyramine and partial cloning of a putative tyrosine decarboxylase gene. Curr. Microbiol. 55, 205-210.

Arena, P. A., Russo, P., Capozzi, V., Beneduce, L., and Spano, G. (2010). Effect of abiotic stress conditions on expression of the Lactobacillus brevis IOEB 9809 tyrosine decarboxylase and agmatine deiminase genes. Ann. Microbiol. 61, 179-183.

Arlorio, M., Coïsson, J. D., Travaglia, F., Capasso, M., Rinaldi, M., and Martelli, A. (2003). Proteolysis and production of biogenic amines in toma piemontese PDO cheese during ripening. Ital. J. Food Sci. 15, 395-404.

Bearson, S., Bearson, B., and Foster, J. W. (1997). Acid stress responses in enterobacteria. FEMS Microbiol. Lett. 147, 173-180.

Beresford, T. P., and Williams, A. (2004). "The microbiology of cheese ripening," in Cheese Chemistry, Physics and Microbiology, eds P. F. Fox, P. L. H. McSweeney, T. M. Cogan, and T. P. Guinee (Amsterdam: Elsevier), 287-317.

Blackwell, B. (1963). Hypertensive crisis due to monoamine-oxidase inhibitors. Lancet 2, 849-850.

Bodmer, S., Imark, C., and Kneubühl, M. (1999). Biogenic amines in foods: histamine and food processing. Inflamm. Res. 48, 296-300.
Bonetta, S., Bonetta, S., Carraro, E., Coïsson, J. D., Travaglia, F., and Arlorio, M. (2008). Detection of biogenic amine producer bacteria in a typical Italian goat cheese. J. Food Prot. 71, 205-209.

Burdychova, R., and Komprda, T. (2007). Biogenic amine-forming microbial communities in cheese. FEMS Microbiol. Lett. 276, 149-155.

Bunková, L., Bunka, F., Hlobilová, M., Vanátková, Z., Nováková, D., and Dráb, V. (2009). Tyramine production of technological important strains of Lactobacillus, Lactococcus and Streptococcus. Eur. Food Res. Technol. 229, 533-538.

Bunková, L., Bunka, F., Mantlová, G., Cablová, A., Sedlácek, I., Švec, P., Pachlová, V., and Krácmar, S. (2010). The effect of ripening and storage conditions on the distribution of tyramine, putrescine and cadaverine in Edam-cheese. Food Microbiol. 27, 880-888.

Calles-Enríquez, M., Eriksen, B. H., Andersen, P. S., Rattray, F. P., Johansen, A. H., Fernández, M., Ladero, V., and Álvarez, M. A. (2010). Sequencing and transcriptional analysis of the Streptococcus thermophilus histamine biosynthesis gene cluster: factors that affect differential $h d c A$ expression. Appl. Environ. Microbiol. 76, 6231-6238.

Chander, H., Batish, V. H., Babu, S., and Bhatia, K. L. (1988). Studies on optimal conditions for amine production by E. coli. Milchwissenschaft 43, 90-91.

Chander, H., Batish, V. H., Babu, S., and Singh, R. S. (1989). Factors affecting amine production by a selected strain of Lactobacillus bulgaricus. J. Food Sci. 54, 940-942.

without BA synthesis capability, and low storage temperatures, would contribute to reduce BA accumulation and to produce healthier cheeses. For this purpose, a number of quantitative PCR-based methods allowing detection and quantification BAproducer microorganisms either in starters, raw material, or even during cheesemaking and ripening processes have been described (Ladero et al., 2010b,c, 2012b).

In addition, more research is needed to increase our knowledge in two directions: (i) the effects of BA on the health of the consumers and (ii) the factors involved in the synthesis of $\mathrm{BA}$ in order to develop new strategies to prevent their accumulation.

\section{ACKNOWLEDGMENTS}

This work was performed with financial support from the Ministry of Science and Innovation, Spain (AGL2010-18430) and the European Community's Seventh Framework Programme (BIAMFOOD-211441). Daniel M. Linares and Beatriz del Río are recipient of a JAE-Doc contract (CSIC).

Chaves-López, C., Serio, A., Martuscelli, M., Paparella, A., Osorio, E., and Suzzi, G. (2011). Microbiological characteristics of Kumis, a traditional fermented Colombian milk, with particular emphasis on enterococci population. Food Microbiol. 28, 1041-1047.

Coton, M., Delbés-Paus, C., Irlinger, F., Desmasures, N., Le Fleche, A., Stahl, V., Montel, M. C., and Coton, E. (2011). Diversity and assessment of potential risk factors of Gramnegative isolates associated with French cheeses. Food Microbiol. 29, 88-98.

Coutts, R. T., Baker, G. B., and Pasutto, F. M. (1986). Foodstuffs as sources of psychoactive amines and their precursors: content significance and identification. Adv. Drug Res. 15, 169-232.

Crow, V., Curry, B., and Hayes, M. (2001). The ecology of non-starter lactic acid bacteria (NSLAB) and their uses as adjuncts in New Zeland Cheddar. Int. Dairy J. 11, 275-283.

Custódio, F. B., Tavares, E., and Glória, M. B. (2007). Extraction of bioactive amines from grated Parmesan cheese using acid, alkaline and organic solvents. J. Food Compost. Anal. 20, 280-288.

Delbès-Paus, C., Pochet, S., Helinck, S., Veisseire, P., Bord, C., Lebecque, A., Coton, M., Desmasures, N., Coton, E., Irlinger, F., and Montel, M. C. (2012). Impact of Gramnegative bacteria in interaction with a complex microbial consortium on biogenic amine content and sensory characteristics of an uncooked pressed cheese. Food Microbiol. 30, 74-82.

Delgado, S., and Mayo, B. (2004). Phenotypic and genetic diversity of
Lactococcus lactis and Enterococcus spp. strains isolated from Northern Spain starter-free farmhouse cheeses. Int. J. Food Microbiol. 90, 309-319.

EFSA Panel on Biological Hazards (BIOHAZ). (2011). Scientific opinion on risk based control of biogenic amine formation in fermented foods. EFSA J. 9, 2393.

Fadda, S., Vignolo, G., and Oliver, G. (2001). Tyramine degradation and tyramine/histamine production by lactic acid bacteria and Kocuria strains. Biotechnol. Lett. 23, 2015-2019.

Fernández, M., Flórez, A. B., Linares, D. M., Mayo, B., and Álvarez, M. A. (2006a). Early PCR detection of tyramine-producing bacteria during cheese production. J. Dairy Res. 73, 318-321.

Fernández, M., del Río, B., Linares, D. M., Martín, M. C., and Álvarez, M. A. (2006b). Realtime polymerase chain reaction for quantitative detection of histamineproducing bacteria: use in cheese production. J. Dairy Sci. 89, 3763-3769.

Fernández, M., Linares, D. M., and Álvarez, M. A. (2004). Sequencing of the tyrosine decarboxylase cluster of Lactococcus lactis IPLA 655 and the development of a PCR method for detecting tyrosine decarboxylating lactic acid bacteria. J. Food Prot. 67, 2521-2529.

Fernández, M., Linares, D. M., del Rio, B., Ladero, V., and Álvarez, M. A. (2007a). HPLC quantification of biogenic amines in cheeses: correlation with PCRdetection of tyramine-producing microorganisms. J. Dairy Res. 74, 276-282. 
Fernández, M., Linares, D. M., Rodríguez, A., and Álvarez, M. A. (2007b). Factors affecting tyramine production in Enterococcus durans IPLA655. Appl. Microbiol. Biotechnol. 73, 1400-1406.

Fernández-García, E., Tomillo, E. J., and Nuñez, M. (2000). Formation of biogenic amines in raw milk Hispanico cheese manufactured with proteinases and different levels of starter culture. J. Food Prot. 63, 1551-1555.

Fernández-García, E., Tomillo, J., and Núñez, M. (1999). Effect of added proteinases and level of starter culture on the formation of biogenic amines in raw milk Manchego cheese. Int. J. Food Microbiol. 52, 189-196.

Gale, E. F. (1946). The bacterial amino acid decarboxylase. Adv. Enzymol. 6, 1-32.

Galgano, F., Suzzi, G., Favati, F., Caruso, M., Martuscelli, M., Gardini, F., and Salzano, G. (2001). Biogenic amines during ripening in 'Semicotto Caprino' Cheese. Int. J. Food Sci. Technol. 36, 153-160.

García-Ruiz, A., González-Rompinelli, E. M., Bartolomé, B., and MorenoArribas, M. V. (2011). Potential of wine-associated lactic acid bacteria to degrade biogenic amines. Int. J. Food Microbiol. 148, 115-120.

Gardini, F., Martuscelli, M., Caruso, M. C., Galgano, F., Crudele, M. A., Favati, F., Guerzoni, M. E., and Suzzi, G. (2001). Effect of pH, temperature and $\mathrm{NaCl}$ concentration on the growth kinetic, proteolytic activity and biogenic amines production of Enterococcus faecalis. Int. J. Food Microbiol. 64, 105-117.

Gardini, F., Martuscelli, M., Crudele, M. A., Paparella, A., and Suzzi, G. (2002). Use of Staphylococcus xylosus as a starter culture in dried sausages: effect on the biogenic amine content. Meat Sci. 61, 275-283.

Gardini, F., Tofalo, R., Belletti, N., Iucci, L., Suzzi, G., Torriani, S., Guerzoni, M. E., and Lanciotti, R. (2006). Characterization of yeasts involved in the ripening of Pecorino Crotonese cheese. Food Microbiol. 23, 641-648.

Gennaro, M. C., Gianotti, V., Marengo, E., Pattono, D., and Turi, R. M. (2003). A chemometric investigation of the effect of the cheesemaking process on contents of biogenic amines in a semi-hard Italian cheese (Toma). Food Chem. 82, 545-551.

Hanington, E. (1967). Preliminary reports on tyramine in headache. BMJ 2, 550-551.

Innocente, N., and D'Agostin, P. (2002). Formation of biogenic amines in a typical semihard Italian cheese. J. Food Prot. 65, 1498-1501.

Joosten, H. M., and Northolt, M. D. (1987). Conditions allowing the formation of biogenic amines in cheese 2. Decarboxylative properties of some non starter bacteria. Neth. Milk Dairy J. 41, 259-280.

La Gioia, F., Rizzotti, L., Rossi, F., Gardini, F., Tabanelli, G., and Torriani, S. (2011). Identification of a tyrosine decarboxylase gene $(t d c A)$ in Streptococcus thermophilus 1TT45 and analysis of its expression and tyramine production in milk. Appl. Environ. Microbiol. 77, 1140-1144.

Ladero, V., Calles-Enriquez, M., Fernández, M., and Álvarez, M. A. (2010a). Toxicological effects of dietary biogenic amines. Curr. Nutr. Food Sci. 6, 145-156.

Ladero, V., Martínez, N., Martín, M. C., Fernández, M., and Álvarez, M. A. (2010b). qPCR for quantitative detection of tyramine-producing bacteria in dairy products. Food Res. Int. 43, 289-295.

Ladero, V., Fernández, M., Cuesta, I., and Álvarez, M. A. (2010c). Quantitative detection and identification of tyramine-producing enterococci and lactobacilli in cheese by multiplex qPCR. Food Microbiol. 27, 933-939.

Ladero, V., Fernández, M., and Álvarez, M. A. (2009). Effect of post-ripening processing on the histamine and histamine-producing bacteria contents of different cheeses. Int. Dairy J. 19, 759-762.

Ladero, V., Fernández, M., CallesEnríquez, M., Sánchez-Llana, E., Cañedo, E., Martín, M. C., and Álvarez, M. A. (2012a). Is biogenic amines production a straindependent trait in enterococci?. Food Microbiol. 30, 132-138.

Ladero, V., Cañedo, E., Martín, M. C., Fernández, M., and Álvarez, M. A. (2012b). Multiplex qPCR for the detection, quantification and identification of putrescineproducing lactic acid bacteria in dairy products. Food Control. 27, 307-313.

Ladero, V., Linares, D. M., Fernández, M., and Álvarez, M. A. (2008). Real time quantitative PCR detection of histamine-producing lactic acid bacteria in cheese: relation with histamine content. Food Res. Int. 41, 1015-1019.

Ladero, V., Rattray, F. P., Mayo, B., Martín, M. C., Fernández, M., and Álvarez, M. A. (2011a). Putrescine producing Lactococcus lactis: sequencing and transcriptional analysis of the biosynthesis gene cluster. Appl. Environ. Microbiol. 77, 5507-5511.

Ladero, V., Sánchez-Llana, E., Fernández, M., and Álvarez, M. A. (2011b). Survival of biogenic amine-producing dairy LAB strains at pasteurisation conditions. Int. J. Food Sci. Technol. 46, 516-521.

Lane, C. N., and Fox, R. E. (1996). Contribution of starter and adjunct lactobacilli to proteolysis in Cheddar cheese during ripening. Int. Dairy J. 6, 715-728.

Latorre-Moratalla, M. L., Bosch-Fusté, J., Lavizzari, T., Bover-Cid, S., Veciana-Nogués, M. T., and VidalCarou, M. C. (2009). Validation of an ultra high pressure liquid chromatographic method for the determination of biologically active amines in food. J. Chromatogr. A 1216, 7715-7720.

Leuschner, R. G., and Hammes, W. P. (1998). Degradation of histamine and tyramine by Brevibacterium linens during surface ripening of Munster cheese. J. Food Prot. 61, 874-878.

Leuschner, R. G., Heidel, M., and Hammes, W. P. (1998). Histamine and tyramine degradation by food fermenting microorganisms. Int. J. Food Microbiol. 39, $1-10$.

Lewis, M. J. (2003). "Improvements in the pasteurisation and sterilisation of milk," in Dairy Processing: Improving Quality, ed. G. Smit (Cambridge: Woodhead Publishing Limited), 81-103.

Linares, D. M., Fernández, M., Martín, M. C., and Álvarez, M. A. (2009). Tyramine biosynthesis in Enterococcus durans is transcriptionally regulated by the extracellular $\mathrm{pH}$ and tyrosine concentration. Microb. Biotechnol. 2, 625-633.

Linares, D. M., Martín, M. C., Ladero, V., Álvarez, M. A., and Fernández, M. (2011). Biogenic amines in dairy products. Crit. Rev. Food Sci. Nutr. 51, 691-703.

Llacer, J. L., Polo, L. M., Tavarez, S., Alarcon, B., Hilario, R., and Rubio, V. (2007). The gene cluster for agmatine catabolism of Enterococcus faecalis: study of recombinant putrescine transcarbamylase and agmatine deiminase and a snapshot of agmatine deiminase catalyzing its reaction. J. Bacteriol. 189, 1254-1265.

Lucas, P. M., Blancato, V. S., Claisse, O., Magni, C., Lolkema, J. S., and
Lonvaud-Funel, A. (2007). Agmatine deiminase pathway genes in $\mathrm{Lac}$ tobacillus brevis are linked to the tyrosine decarboxylation operon in a putative acid resistance locus. Microbiology 153, 2221-2230.

Lucas, P. M., Wolken, W. A., Claisse, O., Lolkema, J. S., and Lonvaud-Funel, A. (2005). Histamine-producing pathway encoded on an unstable plasmid in Lactobacillus hilgardii 0006. Appl. Environ. Microbiol. 71, 1417-1424.

Lynch, C. M., McSweeney, R. L., Fox, R. E, Cogan, T. M., and Drinan, E. D. (1997). Contribution of starter lactococci and non-starter lactobacilli to proteolysis in Cheddar cheese with a controlled microflora. Lait 77, 441-459.

Marcobal, A., Martin-Alvarez, P. J., Moreno-Arribas, M. V., and Muñoz, R. (2006a). A multifactorial design for studying factors influencing growth and tyramine production of the lactic acid bacteria Lactobacillus brevis CECT 4669 and Enterococcus faecium BIFI-58. Res. Microbiol. 157, 417-424.

Marcobal, A., de las Rivas, B., MorenoArribas, M. V., and Muñoz, R. (2006b). Evidence for horizontal gene transfer as origin of putrescine production in Oenococcus oeni RM83. Appl. Environ. Microbiol. 72, 7954-7958.

Marcobal, A., de Las Rivas, B., and Muñoz, R. (2006c). First genetic characterization of a bacterial $\beta$-phenylethylamine biosynthetic enzyme in Enterococcus faecium RM58. FEMS Microbiol. Lett. 258, 144-149.

Marino, M., Maifreni, V., Moret, S., and Rondinini, G. (2000). The capacity of Enterobacteriaceae species biogenic amines in cheese. Lett. Appl. Microbiol. 31, 169-173.

Martín, M. C., Fernández, M., Linares, D. M., and Álvarez, M. A. (2005). Sequencing, characterization and transcriptional analysis of the histidine decarboxylase operon of Lactobacillus buchneri. Microbiology 151, 1219-1228.

Martuscelli, M., Crudele, M. A., Gardini, F., and Suzzi, G. (2000). Biogenic amine formation and oxidation by Staphylococcus xylosus strains from artisanal fermented sausages. Lett. Appl. Microbiol. 31, 228-232.

Martuscelli, M., Gardini, F., Torriani, S., Mastrocola, D., Serio, A., Chaves-López, C., Schirone, M., and Suzzi, G. (2005). Production of biogenic amines during the ripening of Pecorino 
Abruzzese cheese. Int. Dairy J. 15, 571-578.

Mayer, H. K., Fiechter, G., and Fischer, E. (2010). A new ultra-pressure liquid chromatography method for the determination of biogenic amines in cheese. J. Chromatogr. A 1217, 3251-3257.

Meng, S. Y., and Bennett, G. N. (1992). Nucleotide sequence of the Escherichia coli cad operon: a system for neutralization of low extracellular pH. J. Bacteriol. 174, 2659-2669.

Mercogliano, R., De Felice, A., Chirollo, C., and Cortesi, M. L. (2010). Production of vasoactive amines during the ripening of Pecorino Carmasciano cheese. Vet. Res. Commun. 34, S175-S178.

Mohedano, A. F., Fernández, J., Gaya, P., Medina, M., and Nuñez, M. (1998). Effect of the cysteine proteinase from Micrococcus sp. INIA 528 on the ripening process of Hispanico cheese. J. Dairy Res. 65, 621-630.

Moreno-Arribas, V., and LonvaudFunel, A. (1999). Tyrosine decarboxylase activity of Lactobacillus brevis IOEB 9809 isolated from wine and L. brevis ATCC 367 . FEMS Microbiol. Lett. 180, 55-60.

Moreno-Arribas, V., and LonvaudFunel, A. (2001). Purification and characterization of tyrosine decarboxylase of Lactobacillus brevis IOEB 9809 isolated from wine. FEMS Microbiol. Lett. 195, 103-107.

Muehlenkamp-Ulate, M. R., and Warthesen, J. J. (1999). Evaluation of several non-starter lactobacilli for their influence on Cheddar cheese slurry proteolysis. J. Dairy Sci. 82, 1370-1378.

Muir, D. D., and Banks, J. M. (2003). "Factors affecting the shelf-life of milk and milk products," in Dairy Processing: Improving Quality, ed. G. Smit (Cambridge: Woodhead Publishing Limited), 185-207.

Naila, A., Flint, S., Fletcher, G., Bremer, P., and Meerdink, G. (2010). Control of biogenic amines in food-existing and emerging approaches. J. Food Sci. 75, 139-150.

Nieto-Arribas, P., Seseña, S., Poveda, J. M., Palop, L., and Cabezas, L. (2009). Genotypic and technological characterization of Lactococcus lactis isolates involved in processing of artisanal Manchego cheese. J. Appl. Microbiol. 107, 1505-1517.

Novella-Rodríguez, S., Veciana-Nogués, M. T., Izquerdo-Pulido, M., and Vidal-Carou, M. C. (2003). Distribution of biogenic amines and polyamines in cheese. J. Food Sci. 68, 750-755.

Novella-Rodríguez, S., Veciana-Nogués, M. T., Roig-Sagués, A. X., TrujilloMesa, A. J., and Vidal-Carou, M C. (2002). Influence of starter and nonstarter on the formation of biogenic amine in goat cheese during ripening. J. Dairy Sci. 85, 2471-2478.

Novella-Rodríguez, S., Veciana-Nogués, M. T., and Vidal-Carou, M. C. (2000). Biogenic amines and polyamines in milks and cheeses by ion-pair high performance liquid chromatography. J. Agric. Food Chem. 48, 5117-5123.

Núñez, M., Guillen, A. M., RodríguezMarin, M. A., Marcilla, A. M., Gaya, P., and Medina, M. (1991). Accelerated ripening of ewes' milk Manchego cheese: the effect of neutral proteinases. J. Dairy Sci. 74, 4108-4118.

Ordóñez, A. I., Ibañez, F. C., Torre, P., and Barcina, Y. (1997). Formation of biogenic amines in Idiazabal Ewe's milk cheese: effect of ripening, pasteurization, and starter. J. Food Prot. 60, 1371-1375.

Özdestan, Ö., and Üren, A. (2010). Biogenic amine content of kefir: a fermented dairy product. Eur. Food Res. Technol. 231, 101-107.

Pinho, O., Ferreira, I. M., Mendes, E., Oliveira, B. M., and Ferreira, M. (2001). Effect of temperature on evolution of free amino acid and biogenic amine contents during storage of Azeitão cheese. Food Chem. 75, 287-291.

Pinho, O., Pintado, A. I., Gomes, A. M., Pintado, M. M., Malcata, F. X., and Ferreira, I. M. (2004). Interrelationships among microbiological, physicochemical, and biochemical properties of Terrincho cheese, with emphasis on biogenic amines. J. Food Prot. 67, 2779-2785.

Pircher, A., Bauer, F., and Paulsen, P. (2007). Formation of cadaverine, histamine, putrescine and tyramine by bacteria isolated from meat, fermented sausages and cheeses. Eur. Food Res. Technol. 226, 225-231.

Rabie, M. A., Elsaidy, S., el-Badawy, A. A., Siliha, H., and Malcata, F. X. (2011). Biogenic amine contents in selected Egyptian fermented foods as determined by ion-exchange chromatography. J. Food Prot. 74, 681-685.

Reij, M. W., and Den Aantrekker, E. D. (2004). Recontamination as a source of pathogens in processed foods. Int. J. Food Microbiol. 91, $1-11$.

Repka-Ramírez, M. S., and Baraniuk, J. N. (2002). Histamine in health and disease. Clin. Allergy Immunol. 17, $1-25$.

Rhee, J. E., Rhee, J. H., Ryu, P. Y., and Choi, S. H. (2002). Identification of the cadBA operon from Vibrio vulnificus and its influence on survival to acid stress. FEMS Microbiol. Lett. 208, 245-251.

Roig-Sagués, A. X., Molina, A. P., and Hernandez-Herrero, M. M. (2002). Histamine and tyramine-forming microorganisms in Spanish traditional cheeses. Eur. Food Res. Technol. 215, 96-100.

Russo, P., Spano, G., Arena, M. P., Capozzi, V., Grieco, F., and Beneduece, L. (2010). Are consumers aware of the risks related to biogenic amines in food? Curr Res. Technol. Edu. Top. Appl. Microbiol. Microb. Biotechnol. 1087-1095.

Santos, W. C., Souza, M. R., Cerqueira, M. O., and Glória, M. B. (2003). Bioactive amines formation in milk by Lactococcus in the presence or not of rennet and $\mathrm{NaCl}$ at 20 and $32^{\circ} \mathrm{C}$. Food Chem. 81, 595-606.

Schelp, E., Worley, S., Monzingo, A. F., Ernst, S., and Robertus, J. D. (2001). $\mathrm{pH}$ induced structural changes regulate histidine decarboxylase activity in Lactobacillus 30a. J. Mol. Biol. 306, 727-732.

Schirone, M., Tofalo, R., Mazzone, G., Corsetti, A., and Suzzi, G. (2011). Biogenic amine content and microbiological profile of Pecorino di Farindola cheese. Food Microbiol. 28, 128-136.

Serio, A., Paparella, A., Chaves-López, C., Corsetti, A., and Suzzi, G. (2007). Enterococcus populations in Pecorino Abruzzese cheese: biodiversity and safety aspects. J. Food Prot. 70, 1561-1568.

Souci, S. W., Fachmann, W., and Kraut, H. (2000). Food Composition and Nutrition Tables. Stuttgart: Medpharm GmbH Scientific Publishers.

Soufleros, E. H., Bouloumpasi, E. Zotou, A., and Lokou, Z. (2007). Determination of biogenic amines in Greek wines by HPLC and ultraviolet detection after dansylation and examination of factors affecting their presence and concentration. Food Chem. 101, 704-716.

Spano, G., Russo, P., Lonvaud-Funel, A., Lucas, P., Alexandre, H., Grandvalet, C., Coton, E., Coton, M., Barnavon, L., Bach, B., Rattray, F., Bunte, A., Magni, C., Ladero, V., Alvarez, M., Fernández, M., Lopez, P., de Palencia, P. F., Corbi, A., Trip, H., and Lolkema,
J. S. (2010). Biogenic amines in fermented foods. Eur. J. Clin. Nutr. 64, S95-S100.

Stratton, J. E., Hutkins, R. W., and Taylor, S. L. (1991). Biogenic amines in cheese and other fermented foods: a review. J. Food Prot. 54, 460-470.

Straub, B. W., Tichaczek, P. S., Kicherer, M., and Hammes, W. P. (1994). Formation of tyramine by Lactobacillus curvatus LTH972. Z. Lebensm. Unters. Forsch. 199, 9-12.

Sumner, S. S., Roche, F., and Taylor, S. L. (1990). Factors controlling histamine production in swiss cheese inoculated with Lactobacillus buchneri. J. Dairy Sci. 73, 3050-3058.

Sumner, S. S., Speckhard, H. W., Somers, E. B., and Taylor, S. L. (1985). Isolation of histamine-producing Lactobacillus buchneri from Swiss cheese implicated in a food poisoning outbreak. Appl. Environ. Microbiol. 50, 1094-1096.

Suzzi, G., Schirone, M., Martuscelli, M., Gatti, M., Fornasari, M. E., and Neviani, E. (2003). Yeasts associated with Manteca. FEMS Yeast Res. 3, 159-166.

ten Brink, B., Damink, C., Joosten, H. M., and Huis in't Veld, J. H. (1990). Occurrence and formation of biologically active amines in foods. Int J. Food Microbiol. 11, 73-84.

Teodorovic, V., Buncic, S., and Smiljanic, D. (1994). A study of factors influencing histamine production in meat. Fleischwirtschaft 74, 170-172.

Torriani, S., Gatto, V., Sembeni, S., Tofalo, R., Suzzi, G., Belletti, N., Gardini, F., and Bover-Cid, S. (2008). Rapid detection and quantification of tyrosine decarboxylase gene $(t d c)$ and its expression in Gram-positive bacteria associated with fermented foods using PCR-based methods. $J$. Food Prot. 71, 93-101.

Valsamaki, K., Michaelidou, A., and Polychroniadou, A. (2000). Biogenic amine production in Feta cheese. Food Chem. 71, 259-266.

Varnam, A. H., and Sutherland, J. P. (1994). Milk and Milkproducts: Technology, Chemistry and Microbiology. London: Chapman \& Hall, 451.

Wolken, W. A., Lucas, P. M., LonvaudFunel, A., and Lolkema, J. S. (2006). The mechanism of the tyrosine transporter TyrP supports a proton motive tyrosine decarboxylation pathway in Lactobacillus brevis. $J$. Bacteriol. 188, 2198-2206.

Wyder, M. T., Bachmann, H. P., and Puhan, Z. (1999). Role of selected yeasts in cheese ripening: an evaluation in foil wrapped Raclette cheese. Lebensm. Wiss. Technol. 32, 333-343. 
Zaman, M. Z., Abu-Bakar, F., Jinap, S., and Bakar, J. (2011). Novel starter cultures to inhibit biogenic amines accumulation during fish sauce fermentation. Int. J. Food Microbiol. 145, 84-91.

Conflict of Interest Statement: The authors declare that the research was conducted in the absence of any commercial or financial relationships that could be construed as a potential conflict of interest.

Received: 09 February 2012; paper pending published: 29 February 2012; accepted: 27 April 2012; published online: 28 May 2012
Citation: Linares DM, del Río B, Ladero V, Martínez N, Fernández M, Martín MC and Álvarez MA (2012) Factors influencing biogenic amines accumulation in dairy products. Front. Microbio. 3:180. doi: 10.3389/fmicb.2012.00180

This article was submitted to Frontiers in Food Microbiology, a specialty of Frontiers in Microbiology.
Copyright (c) 2012 Linares, del Río, Ladero, Martínez, Fernández, Martín and Álvarez. This is an open-access article distributed under the terms of the Creative Commons Attribution Non Commercial License, which permits noncommercial use, distribution, and reproduction in other forums, provided the original authors and source are credited. 